\title{
Gender and national differences in emotional intelligence and empathy: Comparison of Croatian and Portuguese samples
}

\author{
Jelena Pongrac, Tamara Mohorić and Petra Anić* \\ Department of Psychology, University of Rijeka, Croatia
}

\begin{abstract}
The study focused on the relationship of emotional and cognitive components of empathy with emotional intelligence abilities (labelling, understanding, and regulating emotions). Since both emotional intelligence and empathy have important role in a person's socio-emotional health and well-being, we need to better understand the relations between these two related constructs. Additionally, having samples from two different countries enabled us comparison on the national level. Two samples of adults participated in the study, namely from Croatia $(N=138)$ and Portugal $(N=138)$. We found significant moderate correlations between empathy and emotional intelligence measures in both samples. Four dimensions from the Interpersonal Responsivity Index (IRI; empathic concerns, fantasy, personal distress and perspective-taking) had significant moderate correlations with each other, with similar patterns of correlations in both samples. The strongest correlations were found for the TEQ (affective component of empathy) and perspective-taking (cognitive component of empathy) and different emotional intelligence components. Participants in the Portuguese sample had higher scores on the emotional component of empathy (empathic care and the TEQ), while cognitive component (perspective-taking) was more expressed in the Croatian sample. Participants in the Portuguese sample also had higher scores on all three components of emotional intelligence than participants in the Croatian sample. Regardless of the nationality, women had higher scores on the measures of empathic care, fantasy, perspective-taking and the TEQ, while men scored higher on the measure of personal distress. Regarding emotional intelligence scales, women had higher results on the Perceive and Understand emotions scale.
\end{abstract}

Keywords: affective empathy, cognitive empathy, emotional intelligence, cross cultural studies

\section{Spolne in nacionalne razlike $v$ emocionalni inteligentnosti in empatiji: Primerjava hrvaškega in portugalskega vzorca}

Jelena Pongrac, Tamara Mohorić in Petra Anić* Oddelek za psihologijo, Univerza v Reki, Hrvaška

Povzetek: V raziskavi smo se osredotočili na odnos čustvene in kognitivne komponente empatije s sposobnostmi emocionalne inteligentnosti (označevanje, razumevanje in reguliranje čustev). Ker imata tako emocionalna inteligentnost kot empatija pomembno vlogo v človekovem družbeno-čustvenem zdravju in blagostanju, moramo bolje razumeti odnose med tema dvema sorodnima konstruktoma. Poleg tega smo z vzorci iz dveh različnih držav omogočili primerjavo na nacionalni ravni. V študiji sta sodelovala dva vzorca odraslih oseb iz Hrvaške $(N=138)$ in Portugalske $(N=138)$. V obeh vzorcih smo ugotovili zmerne pomembne korelacije med empatijo in emocionalno inteligentnostjo. Štiri dimenzije iz Indeksa medosebne odzivnosti (IRI; empatične skrbi, fantazije, osebne stiske in perspektive) so imele med seboj pomembno zmerno korelacijo s podobnimi vzorci korelacij v obeh vzorcih. Najvišje so bile korelacije za TEQ (afektivna komponenta empatije) in perspektive (kognitivna komponenta empatije) in različne komponente emocionalne inteligentnosti. Udeleženci portugalskega vzorca so imeli višje izraženo čustveno komponento empatije (empatična skrb in TEQ), kognitivna komponenta (perspektiva) pa je bila bolj izražena v hrvaškem vzorcu. Udeleženci portugalskega vzorca so imeli tudi višje dosežke na vseh treh komponentah emocionalne inteligentnosti kot udeleženci v hrvaškem vzorcu. Ne glede na državljanstvo so ženske imele višje dosežke na lestvicah empatična skrb, fantazija, zavzemanje perspektive in TEQ, medtem ko so moški dosegli višjo stopnjo osebne stiske. Kar se tiče emocionalne inteligentnosti, so ženske imele višje rezultate na ravni zaznavanja in razumevanja čustev.

Ključne besede: čustvena empatija, kognitivna empatija, emocionalna inteligentnost, medkulturne študije

\footnotetext{
*Naslov/Address: dr. Petra Anić, Department of Psychology, University of Rijeka, Sveučilišna avenija 4, 51000 Rijeka, Croatia, e-mail: panic@ffri.hr
}

Članek je licenciran pod pogoji Creative Commons Attribution 4.0 International licence. (CC-BY licenca). The article is licensed under a Creative Commons Attribution 4.0 International License (CC-BY license). 
Although emotional intelligence (EI) can be defined in different ways (e.g., as an ability to reason about emotion, or as a set of traits like motivation and flexibility), the most common definition of EI is the one from the Mayer and Salovey hierarchical model (Mayer \& Salovey, 1997). According to them, emotional intelligence involves different abilities, such as the ability to carry out accurate reasoning about emotions and the ability to use emotions to enhance thought (Mayer, Roberts, \& Barsade, 2008). These abilities include specific skills, such as the ability to accurately identify emotions, or to understand complex connections between different emotions. There are four general areas of these specific skills: emotional perception and identification, use of emotional information in thinking, reasoning about emotions (emotional appraisal, labelling and language), and emotion management. The Four-Branch model of EI (Mayer \& Salovey, 1997) is an integrative model that views overall EI as joining abilities from these four areas. The model also includes key aspects of empathy, especially regarding recognizing other's feelings (Mayer et al., 2008). Higher emotional intelligence scores on different EI measures were associated with higher empathy (Brackett, Rivers, Shiffman, Lerner, \& Salovey, 2006; Caruso, Mayer, \& Salovey, 2002; Ciarrochi, Chan, \& Caputi, 2000; Ciarrochi, Caputi, \& Mayer, 2003; Mayer, Caruso, \& Salovey, 1999).

Just like emotional intelligence, empathy also contributes to a person's ability to understand and respond adaptively to other's emotions, and to succeed in emotional communication (Spreng, McKinnon, Mar, \& Levine, 2009). It includes two components: cognitive (intellectual apprehension of another's emotional state) and emotional (emotional reaction to another's emotional response, without necessarily a cognitive understanding of why a person is suffering). Ioannidou and Konstantikaki (2008) see empathy as the capacity to share and understand another's state of mind or emotions. Empathy includes recognizing others' feelings, the causes of these feelings, and being able to participate in the emotional experience of an individual without becoming part of it (Keen, 2007). It can be provoked by witnessing another's emotional state, by hearing about or even just reading. Empathy was associated with the moral emotion sympathy (or empathic concern) and consequently with prosocial or altruistic behaviour. Also, empathy (both cognitive and emotional component) and trait emotional intelligence were significant predictors of aggressive behaviour (e.g., bullying and victimization; Kokkinos \& Kipritsi, 2012).

Importance of emotional intelligence can be seen in a large number of studies relating EI to various outcomes, e.g. academic success (Parker, Summerfeldt, Hogan, \& Majeski, 2004; Song et al., 2010). Song and her colleagues (2010) found that both EI and general mental ability had a unique power to predict academic performance, and that EI was also related to the quality of social interactions with peers. In a study on the first year medical students, Austin and her colleagues (Austin, Evans, Goldwater, \& Potter, 2005) found that EI partially mediated the effect of gender on the exam performance.
Emotional intelligence also had its importance in predicting individuals' well-being (Gallagher \& Vella-Brodrick, 2008), and life satisfaction (Rey, Extremera, \& Pena, 2011). A metaanalysis done by Martins, Ramalho and Morin (2010) on the relationship between emotional intelligence and health supported previous findings (e.g., Schutte, Malouff, Thorsteinsson, Bhullar, \& Rooke, 2007) that EI was strongly associated with health (mental, psychosomatic, but also physical health), and can be thought of as a plausible health predictor. Just like emotional intelligence, empathy also had an important role in socio-emotional health and well-being of a person (Cassels, Chan. Chung, \& Birch, 2010).

Cultural differences in emotions and emotional intelligence are in the focus of many studies (Matsumoto \& Hwang, 2012; Shao, Doucet, \& Caruso, 2015). According to Shao and his colleagues (2015) some aspects of emotional intelligence are more universal (e.g., emotional perception) while others are more culturally specific (e.g., emotion understanding and emotion regulation). What is considered highly developed emotional intelligence in one country might not be considered the same in the other country. A large cross-cultural study including samples for 13 countries showed some differences between participants on the emotional competence, measured by the Emotional Skills and Competence Questionnaire (ESCQ; Takšić, 2013). Research on cultural differences in empathy also showed that East Asian adolescents and young adults express greater personal distress and less empathic concerns in comparison to Western adolescents (Cassels et al., 2010).

Since various positive outcomes were related to both emotional intelligence and empathy, and results from previous studies indicated some differences in these constructs between nations, the main goal of this study was to examine the relationship between emotional intelligence and empathy in two different samples of adults, namely from Croatia and Portugal. Although research on cultural differences usually focuses on large cultural groups (e.g., Western vs. Eastern culture, or Individualistic vs. Collectivistic cultures) we believe that it is also important to examine the differences between various countries that on first sight belong to the same broad culture (e.g., Western or European), but have a different background and history, and language. Based on previous research (Ioannidou \& Konstantikaki, 2008) we hypothesised there will be a significant positive correlation between different dimensions of emotional intelligence and empathy. Results in many studies (Cliffordson, 2001) showed that women had greater emotional intelligence and empathy than men, so we hypothesised there will be significant difference between men and women in these criteria. According to some researchers (e.g., Costa, Faria, \& Takšić, 2016) samples from Croatia and Portugal differ on the mean level of emotional competence. On the other hand, the Hofstede study (Hofstede, 2001) found more similarities than dissimilarities between these two countries. Based on that notion, there should be no significant differences in the emotional intelligence and empathy between these samples. 


\section{Method}

\section{Participants}

The sample consisted of 276 participants from two countries. Samples from each country had a total of 138 participants, with similar gender and age distributions. Croatian sample consisted of 60 females and 78 males, aged from 18 to 56 years $(M=29, S D=8.3)$, and in the Portuguese sample there were 62 females and 76 males (aged from 18 to 67 years, $M=33, S D=10.5)$. In both samples the majority of participants had high-school education $(55 \%$ in the Croatian, and $42 \%$ in the Portuguese sample), and were single (43\% in the Croatian, $51 \%$ in the Portuguese sample), or in a relationship ( $40 \%$ in the Croatian, $36 \%$ in the Portuguese sample).

\section{Instruments}

The Interpersonal Responsivity Index (IRI, Davis, 1980, 1983; Brdar \& Pokrajac-Bulian, 1993; Limpo, Alves, \& Catro, 2010) measures 4 independent dimensions of empathy. We used the short version of the questionnaire, validated in the Croatian (Brdar \& Pokrajac-Bulian, 1993) and Portuguese language (Limpo et al., 2010). The questionnaire consists of 22 items that measure 4 independent dimensions of empathy: perspective-taking (an ability to adopt the perspective of another person), fantasy (a tendency to strongly identify with characters in books, movies, or plays), empathic concerns (a tendency to experience feelings of warmth, compassion and concern for others undergoing negative experiences), and personal distress (an indication that respondent experienced feelings of discomfort and anxiety when witnessing the negative experiences of others). The answers are given on a 5-point scale $(0$ - does not describes me well to 4 -describes me very well). Cronbach alpha reliability coefficient in different studies varied from .71 to .80 (Cliffordson, 2001). In our study Cronbach alpha was .81 for general empathy (total IRI score) in the Croatian sample (ranging from .68 for empathic concern to .81 for perspective-taking), and .73 (total IRI score) in the Portuguese sample (ranging from .66 for empathic concern to .81 for perspective-taking).

The Toronto Empathy Questionnaire (TEQ; Spreng et al., 2009) represents empathy primarily as an emotional process (e.g., When someone else is feeling excited, I tend to get excited too). According to the authors the TEQ demonstrated strong convergent validity, correlating positively with behavioural measures of social decoding, self-report measures of empathy, and negatively with a measure of Autism symptomatology. The scale has 16 items and a 5-point response scale (1 - Never, 5 - Always). It was translated to both Croatian and Portuguese language using back-translation method and following recommendations for instrument translation stated by van de Vijver and Matsumoto (2011). Since the TEQ was never validated in these two languages, we conducted a confirmatory factor analysis using the "lavaan" package for the $\mathrm{R}$ language and environment for statistical computing (Rosseel, 2012). We tested the one-factor model proposed by authors of the original TEQ. The model was fitted using the default WLSMV estimator for ordered categorical items. In both Croatian and Portuguese sample the model had a poor fit $\left(\mathrm{HRV}: \chi^{2}(104)=273.4, p<.01, \mathrm{CFI}=0.85\right.$, TLI $=0.82$, RM$\mathrm{SEA}=0.11, \mathrm{SRMR}=0.11$; PRT: $\chi^{2}(104)=363.9, p<.01, \mathrm{CFI}$ $=0.79, \mathrm{TLI}=0.76, \mathrm{RMSEA}=0.14, \mathrm{SRMR}=0.12$ ). Additionally, some variables had low (and negative) factor loadings. Two items with low factor loadings (below .30), and possible problems with different understanding of the meaning (item 7 [When a friend starts to talk about his|her problems, I try to steer the conversation towards something else.] and 11 [I become irritated when someone cries.]) were removed from the questionnaire. The new model with 14 items had a slightly better fit $\left(\mathrm{HRV}: \chi^{2}(77)=224.1, p<.01, \mathrm{CFI}=0.86, \mathrm{TLI}=\right.$ 0.83 , RMSEA $=0.11, \mathrm{SRMR}=0.10$; PRT: $\chi^{2}(77)=298.7, p<$ $.01, \mathrm{CFI}=0.82, \mathrm{TLI}=0.78, \mathrm{RMSEA}=0.14, \mathrm{SRMR}=0.11$ ). The 14 item TEQ had relatively good internal consistency in both samples (.83 for the Croatian and .80 for the Portuguese sample). Based on good reliability coefficients we decided to keep the 14 item TEQ in further analysis. Nevertheless, since the one-factor model did not reproduced the data well enough, further validation of the questionnaire is recommended, and when interpreting results obtained with this measure the reader should keep in mind that the one-factor structure was not confirmed via CFA.

The Emotional Skills and Competences Questionnaire (ESCQ, Takšić 1998, 2002) measures different aspects from the emotional intelligence domain. It has three subscales, which assess skills to: Perceive and Understand emotions (e.g., When I see how someone feels, I usually know what has happened to him), Express and Label emotions (e.g., I am able to express my emotions well), and Manage and Regulate emotions (e.g., I do not have difficulty to persuade a friend that there is no reason to worry). It is a self-report measure of emotional intelligence with a 5-point scale $(1-$ Never, 5 - Always). The ESCQ was translated and validated in several languages, including Portuguese (Faria \& Lima Santos, 2005) with satisfying psychometric characteristics (Faria et al., 2006; Takšić et al., 2009). Reliability coefficients were .93 for total ESCQ score in the Croatian sample and .95 in the Portuguese sample. Subscales also showed good internal consistency coefficients ranging from .81 to .95 in both samples.

\section{Procedure}

The questionnaires were administered online. On the first page all the necessary information about the research were clearly stated. It was emphasised that the participation was voluntary and anonymous, and that participants could withdraw at any time without any consequences. Participants first filled out the Interpersonal Responsivity Index (IRI), then the Emotional Skills and Competence Questionnaire (ESCQ), and last the Toronto Empathy Questionnaire (TEQ). At the end, demographic information were gathered. It took about 20 minutes to answer all the questions. Online format of the questionnaires did not allowed for the missing answers. We used the snowball method to collect data, using e-mail addresses and social networks. 


\section{Results}

First we examined the correlations between different measures of empathy and emotional intelligence by calculating Pearson's correlation coefficients. Then we tested the difference on five empathy and three emotional intelligence measures with ANOVA, looking for gender and nationality differences. Descriptive statistics for all used variables are presented in Table 1.

Half of the variables had skewness within acceptable range $( \pm 0.50)$, a conservative criteria suggested for example by Runyon, Coleman and Pittenger (2000). Several variables had skewness lower then of \pm 1 , criteria proposed by Muthen and Kaplan (1985). However, there were two variables with skewness above 1, but according to Tabachnick and Fidell (2007), a distribution can be treated as normal if its skewness does not exceeds \pm 2 or even \pm 3 according to Kline (2005). Based on that, we concluded that skewness of these variables should not affect the obtained results. Since there are so many different criteria for determining the acceptable limits of the skewness and kurtosis, we also visually inspected each variable distribution, as suggested by Tabachnick and Fidell (2007) and concluded that there are no major departures from normality. For the sake of simplicity and coherency it was decided not to alter any variables via normalization procedures.

The results of the correlation analysis are shown in Table 2. Correlation coefficients from the Croatian and Portuguese samples are shown in different rows.

All of the measures of empathy and emotional intelligence were significantly moderately correlated. Four dimensions from the IRI questionnaire (empathic concerns, fantasy, personal distress, and perspective-taking) had low to moderate correlations with each other in both samples (ranging from 0 to .48), with similar patterns of correlations in both samples. The strongest correlations were found between IRI dimensions and the Toronto Empathy Questionnaire, which was expected since both are empathy measures. Both IRI subscales and the TEQ had lower reliability coefficients, which could have affected the results. There were some small differences in the correlations, for example personal distress and TEQ had low but significant correlation in the Croatian sample, but

Table 1. Descriptive statistics for various empathy and emotional intelligence scales

\begin{tabular}{|c|c|c|c|c|c|c|c|}
\hline Variable & Country & Gender & $M$ & $S D$ & Skew & Kurt & $\alpha$ \\
\hline \multirow{4}{*}{ Empathic concerns } & \multirow{2}{*}{ HRV } & $\mathrm{F}$ & 22.12 & 4.00 & \multirow{2}{*}{-0.21} & \multirow{2}{*}{-0.60} & \multirow{2}{*}{.68} \\
\hline & & M & 19.55 & 4.06 & & & \\
\hline & \multirow{2}{*}{ PRT } & $\mathrm{F}$ & 23.56 & 3.65 & \multirow{2}{*}{-0.46} & \multirow{2}{*}{-0.03} & \multirow{2}{*}{.66} \\
\hline & & M & 21.89 & 4.26 & & & \\
\hline \multirow{4}{*}{ Fantasy } & \multirow{2}{*}{ HRV } & $F$ & 22.50 & 4.11 & \multirow{2}{*}{-0.34} & \multirow{2}{*}{-0.28} & \multirow{2}{*}{.79} \\
\hline & & M & 19.44 & 5.02 & & & \\
\hline & \multirow{2}{*}{ PRT } & $\mathrm{F}$ & 22.02 & 4.41 & \multirow{2}{*}{-0.25} & \multirow{2}{*}{-0.48} & \multirow{2}{*}{.79} \\
\hline & & $\mathrm{M}$ & 19.64 & 4.98 & & & \\
\hline \multirow{4}{*}{ Personal distress } & \multirow{2}{*}{ HRV } & $\mathrm{F}$ & 17.98 & 2.24 & \multirow{2}{*}{0.08} & \multirow{2}{*}{1.03} & \multirow{2}{*}{.76} \\
\hline & & M & 16.83 & 2.31 & & & \\
\hline & \multirow{2}{*}{ PRT } & $\mathrm{F}$ & 17.60 & 2.43 & \multirow{2}{*}{-0.16} & \multirow{2}{*}{0.02} & \multirow{2}{*}{.71} \\
\hline & & M & 16.63 & 2.74 & & & \\
\hline \multirow{4}{*}{ Perspective-taking } & \multirow{2}{*}{ HRV } & $\mathrm{F}$ & 19.25 & 3.27 & 030 & 011 & 81 \\
\hline & & $\mathrm{M}$ & 17.67 & 3.98 & -0.39 & -0.11 & .81 \\
\hline & PRT & $\mathrm{F}$ & 19.81 & 3.41 & & & \\
\hline & PRI & $\mathrm{M}$ & 19.47 & 3.38 & -1.06 & 2.20 & .81 \\
\hline & HRV & $\mathrm{F}$ & 55.68 & 6.76 & -0.60 & 068 & 83 \\
\hline TFO & & M & 51.68 & 7.84 & -0.00 & & \\
\hline ILQ & PRT & $\mathrm{F}$ & 57.03 & 5.38 & 076 & 064 & 80 \\
\hline & PK1 & M & 54.38 & 6.96 & -0.10 & 0.04 & .80 \\
\hline & HRV & $\mathrm{F}$ & 54.38 & 7.97 & & & \\
\hline Perceive and Understand emotions (PU) & HKV & M & 50.90 & 8.97 & -0.51 & 0.56 & .89 \\
\hline & PRT & $F$ & 64.69 & 10.29 & 107 & 301 & 03 \\
\hline & PК1 & $\mathrm{M}$ & 63.12 & 11.71 & $-1.0 /$ & 3.01 & .93 \\
\hline & HRV & $\mathrm{F}$ & 49.57 & 10.17 & -058 & 043 & 01 \\
\hline Fynrecs and I ohel amotions (FI) & HRV & $\mathrm{M}$ & 45.00 & 10.16 & -0.58 & -0.43 & .91 \\
\hline 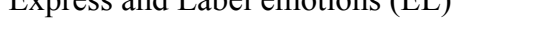 & PRT & $\mathrm{F}$ & 58.11 & 11.85 & -0.74 & 084 & 91 \\
\hline & & $\mathrm{M}$ & 58.99 & 11.37 & -0.14 & & \\
\hline & HRV & $\mathrm{F}$ & 55.08 & 7.58 & 043 & 070 & 81 \\
\hline Manage and Regulate Emotions (MR) & HKV & $\mathrm{M}$ & 53.56 & 7.65 & $-\mathrm{C}$ & 0.19 & .01 \\
\hline 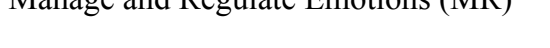 & PRT & $\mathrm{F}$ & 69.06 & 10.22 & -168 & 651 & 83 \\
\hline & PKI & M & 69.62 & 9.18 & -1.08 & 0.31 & .05 \\
\hline
\end{tabular}

Notes. $\mathrm{HRV}=$ Croatia, $\mathrm{PRT}=$ Portugal, $\mathrm{M}=$ male, $\mathrm{F}=$ female, $\mathrm{TEQ}=$ Toronto Empathy Questionnaire, Skew = Skewness, Kurt = Kurtosis, $\alpha=$ Cronbach's $\alpha$ reliability coefficient 
Table 2. Correlation coefficients for measures of empathy and emotional intelligence in the Croatian and the Portuguese sample

\begin{tabular}{|c|c|c|c|c|c|c|c|c|}
\hline & Country & Fantasy & $\begin{array}{c}\text { Personal } \\
\text { distress }\end{array}$ & $\begin{array}{l}\text { Perspective- } \\
\text { taking }\end{array}$ & TEQ & PU & EL & MR \\
\hline \multirow{2}{*}{ Empathic concerns } & HRV & $.48^{* *}$ & $.28^{* *}$ & $.43^{* *}$ & $.79^{* *}$ & $.37^{* *}$ & $.27^{* *}$ & $.27^{* *}$ \\
\hline & PRT & $.42^{* *}$ & .00 & $.37^{* *}$ & $.70^{* *}$ & $.23^{* *}$ & $.38^{* *}$ & $.26^{* *}$ \\
\hline \multirow{2}{*}{ Fantasy } & HRV & & $.22^{*}$ & $.29^{* *}$ & $.45^{* *}$ & $.22^{* *}$ & $.31^{* *}$ & $.25^{* *}$ \\
\hline & PRT & & $.22^{*}$ & $.20^{*}$ & $.34^{* *}$ & $.20^{*}$ & .11 & $.18^{*}$ \\
\hline \multirow{2}{*}{ Personal distress } & HRV & & & .10 & $.23^{*}$ & .14 & -.07 & .08 \\
\hline & PRT & & & .07 & -.02 & -.02 & .07 & .12 \\
\hline \multirow{2}{*}{ Perspective-taking } & HRV & & & & $.50^{* *}$ & $.39^{* *}$ & $.29^{* *}$ & $.48^{* *}$ \\
\hline & PRT & & & & $.51^{* *}$ & $.48^{* *}$ & $.43^{* *}$ & $.50^{* *}$ \\
\hline \multirow{2}{*}{ TEQ } & HRV & & & & & $.46^{* *}$ & $.34^{* *}$ & $.39^{* *}$ \\
\hline & PRT & & & & & $.42^{* *}$ & $.50^{* *}$ & $.44^{* *}$ \\
\hline \multirow{2}{*}{$\begin{array}{l}\text { Perceive and Understand } \\
\text { emotions (PU) }\end{array}$} & HRV & & & & & & $.53^{* *}$ & $.52^{* *}$ \\
\hline & PRT & & & & & & $.62^{* *}$ & $.70^{* *}$ \\
\hline \multirow{2}{*}{$\begin{array}{l}\text { Express and Label } \\
\text { emotions (EL) }\end{array}$} & HRV & & & & & & & $.59^{* *}$ \\
\hline & PRT & & & & & & & $.76^{* *}$ \\
\hline
\end{tabular}

Notes. $\mathrm{HRV}=$ Croatia, $\mathrm{PRT}=$ Portugal; TEQ $=$ Toronto Empathy Questionnaire; MR = Manage and Regulate Emotions ${ }^{*} p<.05,{ }^{* *} p<.01$.

no correlation in the Portuguese sample. Measures of emotional intelligence also showed similar patterns of correlations in both samples. The strongest correlations were found for TEQ (.38 to .47$)$ and perspective-taking (.28 to .50) with different emotional intelligence scales.

We were interested in the differences on the empathy and emotional intelligence scales, so we calculated several 2 (nationality) x 2 (gender) between-subjects ANOVAs. Homogeneity of variance was checked for all ANOVAs. Except for TEQ, this assumption was met by the data. Therefore, we have conducted Welch's test to test for the main effects of nationality and gender and confirmed the results obtained by ANOVA. For the ease of presentation and interpretation, ANOVA results are kept in the paper. To control for the family-wise error, adjusted $p$-values were calculated (Benjamini \& Hochberg, 1995). Means and standard deviations for all measures that were tested were shown in Table 1, and in Table 3 are the results of ANOVAs.

As it is shown in Table 3, there were several significant differences for nationality and gender, and only one significant interaction, i.e., Express and Label emotions (which became insignificant after the Benjamini Hochberg correction). Samples from Croatia and Portugal differed on measures of empathic care, perspective-taking, and the TEQ. Participants in the Portuguese sample express more empathic care and affective empathy (measured by the TEQ), while perspectivetaking was more expressed in the Croatian sample. Participants in the Portuguese sample also had higher scores on all three measures of emotional intelligence than participants in the Croatian sample. With corrections, some of those differences became insignificant, but we can look at the effect sizes for better interpretation. Therefore, there is small to medium sized effect of nationality on empathic care, small effects on perspective taking and TEQ, while its effects on all three emotional intelligence measures could be classified as large, or almost large.
We also found several gender differences. Women had higher scores on the measures of empathic care, fantasy, perspective-taking and the TEQ, while men scored higher on the measure of personal distress. Regarding emotional intelligence scales, women had higher results on the Perceive and Understand emotions scale. Effect sizes of gender vary from small (Perceive and Understand emotions, Personal distress, Perspective taking and TEQ) through small to medium (Empathic concerns and Fantasy).

Only one significant gender $x$ nationality interaction was found (Figure 1). Differences between male and female participants in Expression and Labelling emotions were more pronounced in Croatia than in Portugal, with Portuguese results being generally higher, regardless of gender. However, this effect size is small and should be interpreted with caution.

\section{Discussion}

Empathy and emotional intelligence are two different, but closely related constructs (Spreng et al., 2009), so the main focus of the study was the relationship between these constructs in the two samples from Croatia and Portugal, countries that are different but also have much in common (Hofstede, 2001). We hypothesised positive correlation between different emotional intelligence abilities and empathy, and regarding group differences, we expected to find gender differences, since women have shown better EI abilities in many studies (Petrides \& Furnham 2000). We expected that national differences in empathy and emotional intelligence would be small and insignificant.

As expected, all of the measures of empathy and emotional intelligence were moderately correlated. Empathic concerns, fantasy, personal distress and perspective-taking (from the IRI questionnaire) had similar patterns of correlations in both samples, with strongest correlations with the TEQ. 
Table 3. Results of $2 \times 2$ ANOVAs for empathy and emotional intelligence measures

\begin{tabular}{|c|c|c|c|c|}
\hline Dependent variable & Source & $M S$ & $F(1,272)^{\mathrm{a}}$ & $\eta_{p}^{2}$ \\
\hline \multirow{4}{*}{ Empathic concerns } & Nationality & 244.56 & $15.13^{* *}$ & .053 \\
\hline & Gender & 305.18 & $18.87^{* *}$ & .065 \\
\hline & Interaction & 13.65 & 0.84 & .003 \\
\hline & Error & 16.17 & & \\
\hline \multirow{4}{*}{ Fantasy } & Nationality & 1.29 & 0.06 & .000 \\
\hline & Gender & 502.69 & $22.79^{* *}$ & .077 \\
\hline & Interaction & 8.16 & 0.37 & .001 \\
\hline & Error & 22.06 & & \\
\hline \multirow{4}{*}{ Personal distress } & Nationality & 5.89 & 0.98 & .004 \\
\hline & Gender & 76.12 & $12.67^{* *}$ & .045 \\
\hline & Interaction & 0.58 & 0.10 & .000 \\
\hline & Error & 6.01 & & \\
\hline \multirow{4}{*}{ Perspective-taking } & Nationality & 95.04 & $7.55^{*}$ & .027 \\
\hline & Gender & 62.47 & 4.96 & .018 \\
\hline & Interaction & 26.61 & 2.11 & .008 \\
\hline & Error & 12.59 & & \\
\hline \multirow{4}{*}{ TEQ } & Nationality & 279.22 & $5.93^{*}$ & .021 \\
\hline & Gender & 753.44 & $15.99^{* *}$ & .056 \\
\hline & Interaction & 31.15 & 0.66 & .002 \\
\hline & Error & 47.12 & & \\
\hline \multirow{4}{*}{ Perceive and Understand emotions (PU) } & Nationality & 8637.39 & $87.97^{* *}$ & .244 \\
\hline & Gender & 435.80 & 4.44 & .016 \\
\hline & Interaction & 62.12 & 0.63 & .002 \\
\hline & Error & 98.19 & & \\
\hline \multirow{4}{*}{ Express and Label emotions (EL) } & Nationality & 8638.83 & $72.69^{* *}$ & .211 \\
\hline & Gender & 232.01 & 1.95 & .007 \\
\hline & Interaction & 503.63 & 4.24 & .015 \\
\hline & Error & 118.84 & & \\
\hline \multirow{4}{*}{ Manage and Regulate Emotions (MR) } & Nationality & 15349.13 & $202.61^{* *}$ & .427 \\
\hline & Gender & 15.85 & 0.21 & .001 \\
\hline & Interaction & 73.13 & 0.97 & .004 \\
\hline & Error & 75.76 & & \\
\hline
\end{tabular}

Notes. TEQ $=$ Toronto Empathy Questionnaire, $\eta_{\mathrm{p}}{ }^{2}=$ measure of size effect (partial eta squared).

${ }^{a}$ The asterisks indicate significance after Benjamini Hochberg correction for controlling the family-wise error rate.

${ }^{*} p<.05,{ }^{* *} p<.01$.

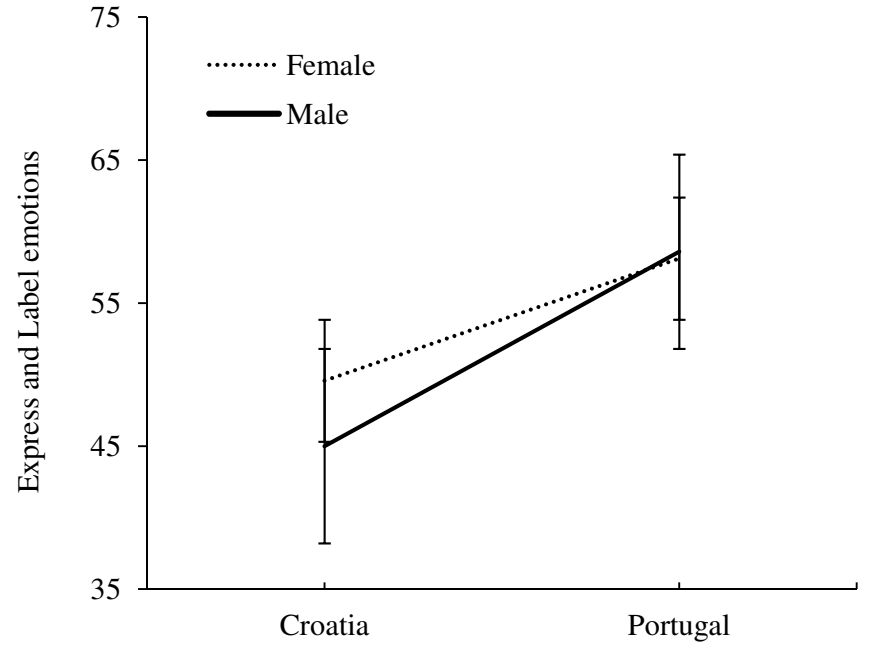

Figure 1. Interaction between gender and nationality when predicting scores on the Express and Label emotions scale.
The IRI measure (Davis, 1983) includes both emotional/affective (empathic concern and personal distress) and cognitive (perspective-taking and fantasy) component of empathy. According to some authors, the most robust components of empathy are represented in the empathic concerns (affective component) and perspective taking (cognitive component) (Alterman, McDermott, Cacciola, \& Rutherford, 2003). On the other hand, the TEQ (Spreng et al., 2009) primarily focuses on an emotional process or an accurate affective insight into the emotional state of another. It is a measure of emotional component of empathic responding. Consistent with this, the strongest correlation was found between the TEQ and empathic concern, since both measure affective/emotional component of empathy. Personal distress (another measure of emotional component in the IRI) had low correlation with the TEQ in the Croatian sample, but there was no correlation between these two measures in the Portuguese sample. As expected, cognitive component of empathy (Perspective-taking and fantasy) had lower correlations with the TEQ than 
emotional component measure, but these correlations were still moderate suggesting that both emotional and cognitive component are necessary to fully understand empathic behaviour.

Emotional intelligence abilities showed moderate to strong correlations with different measures of empathy. Lowest correlations were found for personal distress (measure of emotional component of empathy). According to the results, there was no correlation between person's emotional intelligence and feeling of personal discomfort while observing someone in distress. A person can be able to perceive, understand and manage emotions (her own and others), but still keep a distance and not feel the distress of another person. Some authors regard personal distress to be a measure of anxiety, discomfort and a loss of control in negative environments (Spreng et al., 2009), and not a measure that taps the central component of empathy (Cliffordson, 2001). If we define a personal distress as a measure of emotional self-control and not empathy, we would expect only correlations with manage and regulate subscale from the ESCQ. The strongest correlations were found for perspective-taking (cognitive component) and the TEQ (emotional component) with emotional intelligence scales. If a person has the abilities to perceive, understand and manage emotions, it will be more prone to empathy. The results are in accordance with recent empathy theories, which emphasize the necessity of understanding another's emotions in order to be able to form an empathic response (Bernieri, 2001).

We found several significant differences for nationality and gender, and only one significant interaction. Participants in the Portuguese sample express more emotional component of empathy (empathic care and the TEQ), while cognitive component (perspective-taking) is more expressed in the Croatian sample. Participants in the Portuguese sample also have higher scores on all three measures of emotional intelligence than participants in the Croatian sample. Costa et al., (2016) also compared results on the ESCQ between the Portuguese and the Croatian sample and concluded that some of the differences found between countries may be a consequence of dissimilarities between the cultural settings of Croatia and Portugal. These differences mostly pertained to the Perceive and Understand subscale, which is probably most influenced by culture. According to Hofstede (2001), Croatia and Portugal show similar relatively low scores on Individualism (CRO: 33, PRT: 27), which makes both countries collectivistic. In the collectivistic countries the society fosters strong relationships where everyone takes responsibility for fellow members of their group (Hofstede, 2001), an environment in which both empathy and emotional intelligence abilities are valuable. Also, both countries are qualified as Feminine, meaning that the dominant values in the society are caring for others and quality of life. The largest difference was found on the Long term orientation (CRO: 58, PT: 28). Croatian culture is more pragmatic, while Portuguese culture prefers normative over pragmatic.

We also found several gender differences. Women have higher scores on measures of empathic care, fantasy, perspective-taking and the TEQ, while men scored higher on the measure of personal distress. Regarding emotional intel- ligence scales, women had higher results on the Perceive and Understand emotions scale. Although studies tend to show the existence of gender differences favouring women in various emotion-related traits and competencies (Petrides \& Furnham 2000; Takšić, Mohorić \& Munjas 2006), the picture is not so clear. Some additional variables might have a significant role in these results. For example, Hess and her colleagues (2000) examined general emotion stereotypes and their influence on self-perception of emotional reactions. They found that women and men are expected to react in different ways in different situations, and that in general these expectations for men and women were endorsed by the individuals themselves. Lopez-Zafra and Gartzia (2014) examined the stereotyped nature of EI instruments and showed that most EI dimensions are biased by gender stereotypes, in terms of being perceived as more characteristic of one gender or the other. Fernandez-Berrocal and his colleagues (Fernandez-Berrocal, Cabello, Castillo, \& Extremera, 2012) found that the gender differences initially reported for EI are mediated completely by age for the branches of facilitation and understanding, and partially by age for the dimension of emotional managing. Authors suggest caution when concluding that gender affects EI in the absence of tests for possible interactions between gender and other variables that may influence EI.

Thus, although found in different studies, gender differences in emotional competence should be interpreted with caution, because they can be related to different expectations about what is (or isn't) an appropriate emotion expression for a specific gender or to other mediating variables. Interestingly, men showed higher results for personal distress scale (cognitive component of the IRI). According to Keen (2007), personal distress is an aversive emotional response also brought on by apprehension of another's emotions. It does not lead to sympathy but it focuses on the self and leads to avoidance.

Only one significant gender $x$ nationality interaction was found: gender differences in expression and labelling emotions were more visible in Croatia than in Portugal. The effect size was small, so it should be interpreted with caution. Observed interaction might point to the differences in culturally defined and acceptable behaviour for men and women in Croatia and Portugal. Expressing and labelling emotions was more common in Portugal for both genders compared to Croatia.

The study has a number of limitations that should be taken into consideration when interpreting results. The snowball method of data collection leaves little control of who is going to answer the questionnaires. Maybe only participants with high enough empathy were willing to make an effort and participate in the study. We haven't controlled any variables regarding culture values that could explain the differences found between Portuguese and Croatian sample. Also, correlational nature does not allow for causal interpretation of the results.

The main focus of the study was on gender and national differences between adult samples from two countries that share common cultural background according to the Hosftede study (2001), but still differ in some historic background. Although both Croatia and Portugal belong to collectivistic cultures, it is possible that Portugal can have more individu- 
alistic and secular features when compared to the Croatian setting (Costa et al., 2016). Since the expression of emotions (both internal and external) can be socially and culturally shaped, it is important to examine these characteristics in different cultures (Parker et. al., 2005). We found small to medium sized effect of nationality on empathic care, small effects on perspective taking and TEQ, while its effects on all three emotional intelligence measures could be classified as large or almost large, indicating there are some differences between Croatian and Portugal sample. This study provides more insight into the relationship of emotional and cognitive component of empathy and emotional intelligence in two different country samples. Since both EI and empathy are found to be significant predictors for various outcomes, it is important to better understand the relationship between these two constructs.

\section{References}

Alterman, A. I., McDermott, P. A., Cacciola, J. S., \& Rutherford, M. J. (2003). Latent structure of the Davis Interpersonal Reactivity Index in methadone maintenance patients. Journal of Psychopathology and Behavioral Assessment, 25, 257-265.

Austin, E. J., Evans, P., Goldwater, R., \& Potter, V. (2005). A preliminary study of emotional intelligence, empathy and exam performance in first year medical students. Personality and Individual Differences, 39, 1395-1405.

Benjamini, Y., \& Hochberg, Y. (1995). Controlling the false discovery rate: A practical and powerful approach to multiple testing. Journal of the Royal Statistical Society Series B, 57, 289-300.

Bernieri, F. J. (2001). Toward a taxonomy of interpersonal sensitivity. In J. Hall \& F. Bernieri (Eds.), Interpersonal sensitivity: Theory and measurement (pp. 3-20). Mahwah, NJ, USA: Lawrence Erlbaum Associates.

Brackett, M. A., Rivers, S. E., Shiffman, S., Lerner, N., \& Salovey P. (2006). Relating emotional abilities to social functioning: A comparison of self-report and performance measures of emotional intelligence. Journal of Personality and Social Psychology, 91, 780-795.

Brdar, I., \& Pokrajac-Bulian, A. (1993). Predstavlja li empatija dio socijalne kompetencije [Is empathy part of social competence]? Godišnjak Zavoda za psihologiju [Yearbook of Association of Psychology], 2, 23-29.

Caruso, D. R., Mayer, J. D., \& Salovey P. (2002). Relation of an ability measure of emotional intelligence to personality. Journal of Personality Assessment, 79, 306-320.

Cassels, T. G., Chan, S., Chung, W. C., \& Birch, S. A. J. (2010). The role of culture in affective empathy: Cultural and bicultural differences. Journal of Cognition and Culture, 10, 309-326.

Ciarrochi, J. V., Caputi, P., \& Mayer, J. D. (2003). The distinctiveness and utility of a measure of trait emotional awareness. Personality and Individual Differences, 34, 1477-1490.

Ciarrochi, J. V., Chan, A. Y., \& Caputi, P. (2000). A critical evaluation of the emotional intelligence concept. Personality and Individual Differences, 28, 539-561.
Cliffordson, C. (2001). Parents' judgments and students' self-judgments of empathy: The structure of empathy and agreement of judgments based on the Interpersonal Reactivity Index (IRI). European Journal of Psychological Assessment, 17, 36-47.

Costa, A., Faria, L., \& Takšić, V. (2016). Cross-cultural invariance of emotional skills and competence questionnaire between Portugal and Croatia. The Spanish Journal of Psychology, 19, e31.

Davis, M. H. (1980). A multidimensional approach to individual differences in empathy. Catalog of Selected Documents in Psychology, 10, 3-18.

Davis, M. H. (1983). Measuring individual differences in empathy: Evidence for a multidimensional approach. Journal of Personality and Social Psychology, 44, 113-126.

Faria, L., \& Lima Santos, N. (2005). Adaptation of the Emotional Skills and Competence Questionnaire (ESCQ) to the Portuguese context. Paper presented at the Symposium "Cross-cultural validation of Emotional Skills and Competence Questionnaire (ESCQ)", at the 9th European Congress of Psychology, Granada, Spain, July 3-8.

Faria, L., Lima Santos, N., Takšić, V., Räty, H., Molander, B., Holmström, S., \& Toyota, H. (2006). Cross-cultural validation of the Emotional Skills and Competence Questionnaire (ESCQ). Psicologia, 20, 95-127.

Fernández-Berrocal, P., Cabello, R., Castillo, R., \& Extremera, N. (2012). Gender differences in emotional intelligence: The mediating effect of age. Behavioral Psychology / Psicología Conductual, 20, 77-89.

Gallagher, E. N., \& Vella-Brodrick, D. A. (2008). Social support and emotional intelligence as predictors of subjective well-being. Personality and Individual Differences, 44, 1551-1561.

Hess, U., Senecal, S., Kirouac. G., Herrera, P., Philippot, P., \& Kleck, R. E. (2000). Emotional expressivity in men and women: Stereotypes and self-perceptions. Cognition and Emotion, 14, 609-642.

Hofstede, G. (2001). Culture's consequences: Comparing values, behaviours, institutions, and organizations across nations ( $2^{\text {nd }}$ ed.). Thousand Oaks, CA, USA: Sage Publications.

Ioannidou, F., \& Konstantikaki, V. (2008). Empathy and emotional intelligence: What is it really about? International Journal of Caring Sciences, 1, 118-123.

Keen, S. (2007). Empathy and the novel. New York, NY, USA: Oxford University Press.

Kline, R. B. (2005). Principles and practice of structural equation modeling ( $2^{\text {nd }}$ ed.). New York, NY; USA: Guilford.

Kokkinos, C.M.,\& Kipritsi,E.(2012). Therelationshipbetween bullying, victimization, trait emotional intelligence, selfefficacy and empathy among preadolescents. Social Psychology of Education, 15, 41-58.

Limpo, T., Alves, R. A., \& Catro, S. L. (2010). Medir a empatia: Adaptacao Portuguesa do Indice de Reactividade Interpessoal [Measuring empathy: Portuguese adaptation of the Interpersonal Reactivity Index]. Laboratorio de Psihologia, 8, 171-184. 
Lopez-Zafra, E., \& Gartzia, L. (2014). Perceptions of gender differences in self-report measures of emotional intelligence. Sex Roles, 70, 479-495.

Martins, A., Ramalho, N., \& Morin, E. (2010). A comprehensive meta-analysis of the relationship between emotional intelligence and health. Personality and Individual Differences, 49, 554-564.

Matsumoto, D., \& Hwang, H. S. (2012). Culture and emotion: The integration of biological and cultural contributions. Journal of Cross-Cultural Psychology, 43, 91-118.

Mayer, J. D., Caruso, D. R., \& Salovey, P. (1999). Emotional intelligence meets traditional standards for an intelligence. Intelligence, 27, 267-298.

Mayer, J. D., Roberts, R. D., \& Barsade, S. G. (2008). Human abilities: Emotional intelligence. Annual Review of Psychology, 59, 507-536.

Mayer, J. D., \& Salovey, P. (1997). What is emotional intelligence? In P. Salovey \& D. Sluyter (Eds.), Emotional development and emotional intelligence: Educational implications (pp. 3-31). New York, NY, USA: Basic Books.

Muthen, B., \& Kaplan, D. (1985). A comparison of some methodologies for the factor analysis of non-normal Likert variables. British Journal of Mathematical and Statistical Psychology, 38, 171-189.

Parker, J. D. A., Saklofske, D. H., Shaughnessy, P. A., Huang, S. H. S., Wood, L. M., \& Eastabrook, J. M. (2005). Generalizability of the emotional intelligence construct: A cross-cultural study of North American aboriginal youth. Personality and Individual Differences, 39, 215-227.

Parker, J. D. A., Summerfeldt, L. J., Hogan, M. J., \& Majeski, S. A. (2004). Emotional intelligence and academic success: Examining the transition from high school to university. Personality and Individual Differences, 36, 163-172.

Petrides, K. V., \& Furnham, A. (2000). Gender differences in measured and self-estimated trait emotional intelligence. Sex Roles, 42(5-6), 449-461.

Rosseel, Y. (2012). lavaan: An R package for structural equation modeling. Journal of Statistical Software, 48(2), 1-36.

Rey, L., Extremera, N., \& Pena, M. (2011). Perceived emotional intelligence, self-esteem and life satisfaction in adolescents. Psychosocial Interventions, 20, 227-234.

Runyon, R. P., Coleman, K. A., \& Pittenger, D. J. (2000). Fundamentals of behavioral statistics. Boston: McGraw-Hill.

Schutte, N. S., Malouff, J. M., Thorsteinsson, E. B., Bhullar, N., \& Rooke, S. E. (2007). A meta-analytic investigation of the relationship between emotional intelligence and health. Personality and Individual Differences, 42, 921-933.

Shao, B., Doucet, L., \& Caruso, D. R. (2015). Universality versus cultural specificity of three emotion domains: Some evidence based on the cascading model of emotional intelligence. Journal of Cross-Cultural Psychology, 46, 229-251.
Song, L. J., Huang, G., Peng, K. Z., Law, K. S., Wong, C., \& Chen, Z. (2010). The differential effects of general mental ability and emotional intelligence on academic performance and social interactions. Intelligence, 38, 137-143.

Spreng, N. R., McKinnon, M. C., Mar, R. A., \& Levine, B. (2009). The Toronto Empathy Questionnaire: Scale development and initial validation of a factor-analytic solution to multiple empathy measures. Journal of Personality Assessment, 91, 62-71.

Tabachnick, B. G., \& Fidell, L. S. (2007). Using multivariate statistics (5th ed.). Boston, MA, USA: Allyn \& Bacon/ Pearson Education.

Takšić, V. (1998.) Validacija konstrukta emocionalne inteligencije [Validation of the Emotional Intelligence Construct] (Unpublished doctoral dissertation). University of Zagreb, Croatia.

Takšić, V. (2002). The importance of emotional intelligence (competence) in positive psychology. Paper presented at the First International Positive Psychology Summit, Washington, DC, USA, October 4-6.

Takšić, V. (2013). Cross-cultural issues in emotional intelligence. Invited symposium at 13th European Congress of Psychology, Stockholm, Sweden, July 9-12.

Takšić, V., Mohorić, T., Bradić, S., Faria, L., Santos, N. L., Pessoa, F., ... Jiang, Q. (2009). Cross-cultural comparison of emotional skills and competencies questionnaire (ESCQ). Paper presented at the II. International Emotional Intelligence Congress, Santander, Spain, September 16-18.

Takšić, V., Mohorić, T., \& Munjas, R. (2006). Emocionalna inteligencija: Teorija, operacionalizacija, primjena $\mathrm{i}$ povezanost $\mathrm{s}$ pozitivnom psihologijom [Emotional intelligence: Theory, operacionalization, application and association with positive psychology]. Društvena istraživanja, 15, 729-752.

van de Vijver, F. J. R., \& Matsumoto, D. (2011). Introduction to the methodological issues associated with cross-cultural research. In F. J. R. van de Vijver \& D. Matsumoto (Eds), Cross-cultural research methods in psychology (pp. 114). Cambridge, United Kingdom: Cambridge University Press. 